\title{
Response of bacteria and phytoplankton to contaminated sediments from Trenton Channel, Detroit River ${ }^{1}$
}

\author{
Russell A. Moll and Pamela J. Mansfield \\ Center for Great Lakes and Aquatic Sciences, The University of Michigan, 2200 Bonisteel Blvd., Ann \\ Arbor, Michigan 48109-2099 USA
}

Key words: contaminated sediment bioassay, phytoplankton, bacteria, primary productivity, heterotrophic activity, Detroit River

\begin{abstract}
Several types of bioassays were used in 1986 and 1987 to investigate the effect of contaminated sediments on natural populations of bacteria and phytoplankton from the Trenton Channel, Detroit River. The approach included the measurement of uptake of ${ }^{3} \mathrm{H}$-glucose or ${ }^{3} \mathrm{H}$-adenine by bacteria and ${ }^{14} \mathrm{C}$ bicarbonate by phytoplankton in the presence of different amounts of Trenton Channel and Lake Michigan (control) sediments. Trenton Channel sediments are contaminated by high levels of toxic organic compounds and metals, especially zinc, lead, and copper. Because levels of biomass of bacteria and phytoplankton varied widely among the different bioassays, it was necessary to adjust uptake rates for biomass. Biomass adjustments were made using acridine orange counts for bacteria and chlorophyll measurements for phytoplankton. The results show a statistically significant suppression of uptake of substrates for both bacteria and phytoplankton with increasing amounts of sediment. Uptake was suppressed as much as 90 percent for bacteria and 93 percent for phytoplankton at $1200 \mathrm{mg} \mathrm{l}^{-1}$ of Trenton Channel sediments compared to bioassays without sediment. Uncontaminated Lake Michigan sediment suppressed uptake much less than Detroit River sediment; the difference in suppression of uptake between the two types of sediment was statistically significant for both bacteria and phytoplankton.
\end{abstract}

\section{Introduction}

A large number of studies have attempted to quantify the degree to which various components of the food web are affected by contaminated sediment (Struger et al., 1985; Smith et al., 1985; Pugsley et al., 1985). Some of these have employed bioassay techniques which have evolved into a protocol for the investigation of the effects of contaminated sediment on biota (Mount \& Norberg, 1984). Results of these

\footnotetext{
1 Contribution No. 518 of the Center for Great Lakes and Aquatic Sciences of the University of Michigan.
}

studies lead to the general conclusion that a large number of factors are determinants in the outcomes of the experiments (Munawar et al., 1983). Some of these factors are: the type and concentration of contaminants, the location of the contaminant in the sediment (bound to particle, pore water, etc.), the amount of organic matter in the sediment, the $\mathrm{pH}$ of the sediment and the overlying water, the Eh of the sediment, the temperature, and the intensity of mixing of sediment and water (Munawar et al., 1985). Further, the response of the organisms toward the contaminant depends upon the species and its location in the water column or sediment (Wong et al., 1978). 
In effect, the bioassay of sediment has been species, site, and date specific.

Experience from the Great Lakes Basin supports the same general conclusions discussed above. Results from the Detroit River, Niagara River, and Lakes Erie and Ontario could not be readily extended to other locations within the basin. In effect, these conclusions predicate that a generic bioassay be developed to answer questions from specific locations (U.S. Environmental Protection Agency/U.S. Army Corp of Engineers, 1977). The generic nature of the bioassay allows a common yardstick upon which to compare the degree of toxicity at many locations; this common yardstick can then be used for management decisions.

These concerns were the rationale behind this study which had as its focus contaminant problems associated with sediment in connecting rivers and water bodies. Realistic appraisals of the potential exposure of organisms to toxicants and the response to those exposures was the primary objective of the study. This paper deals with a subset of that problem, the response of phytoplankton and bacteria to contaminated sediment from the Trenton Channel.

The objective of the phytoplankton and bacteria studies was to estimate the suppression of bacterial metabolism and phytoplankton productivity from exposure to Detroit River sediments. From this objective a set of experiments was developed which attempted to determine biological effects with several types of bioassays. These experiments, carried out during the ice-free season in 1986 and 1987, focused on the use of bioassays incorporating the uptake of several different types of radioactive-labelled organic and inorganic compounds. The different bioassays were designed to investigate these hypotheses: (1) the response of microorganisms to contaminated sediment is a combination of a particle effect and a toxic effect, (2) toxicity is primarily from the sediment rather than the pore water, and (3) toxicity varies seasonally and spatially.

The study location was the Trenton Channel which is a branch of the southern portion of the Detroit River west of Grosse Ile. The Trenton

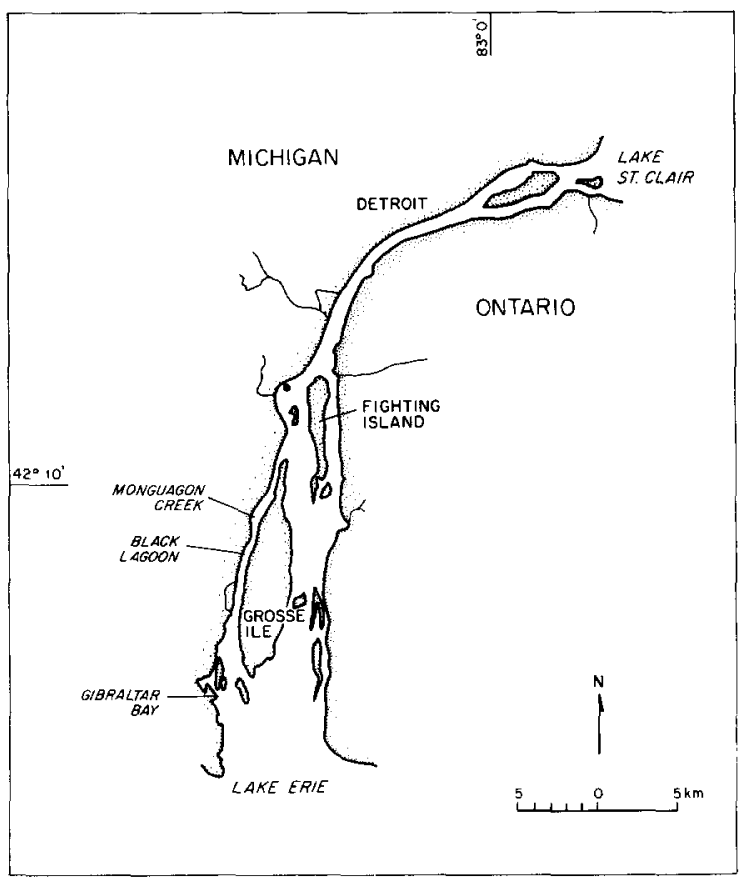

Fig. 1: Sampling locations in the Detroit River.

Channel is analogous to the main portion of the Detroit River in that it is dredged for $2 / 3$ of its length resulting in a hard gravel and rock bottom. Streamflows average $2100 \mathrm{~m}^{3} \mathrm{~s}^{-1}$ in the Trenton Channel which is approximately $1 / 3$ of the total flow of the Detroit River. The dredging activity and the large streamflows keep the bottom of the channel scoured. There are numerous small creeks and embayments which have accumulations of soft sediment along the length of the Trenton Channel. Three of these areas served as the primary sampling locations for this study (Fig. 1).

Much of the western shore of the Trenton Channel is heavily industrialized including steel manufacturing, chemical processing plants, automotive parts manufacturing, and electrical generation facilities (coal fired). In conflict with these industrial processes, the Trenton Channel has many waterfront homes, parks, and boat launching facilities which provide ready access for recreation. The banks of the Trenton Channel also hold a hazardous waste storage site which shows evidence of leaking of toxic materials into the river (Furlong et al., 1988). Finally, the 
Trenton Channel receives extensive input of treated sewage effluent including some of the City of Detroit treatment plant discharge. These numerous environmental insults have resulted in designating the Trenton Channel and the Detroit River as one of the 42 Areas of Concern in the Laurentian Great Lakes.

\section{Methods}

\subsection{Field procedures}

Samples were collected three times during the 1986 field season, spring (May-June), summer (August), and autumn (October), and seven times during 1987, approximately once per month from April through October. Sediment was collected with a Ponar grab from three sites, Monguagon Creek, Black Lagoon, and Gibraltar Bay (Fig. 1). Sediment was stored in $250-\mathrm{ml}$ wide-mouth polyethylene bottles which had been acid-washed and thoroughly rinsed. River water was collected in 20-1 carboys from just below the surface at the center of the Trenton Channel, near each station in 1986 and near Monguagon Creek in 1987. This water was the source of bacteria and phytoplankton populations used in the bioassays. Water and sediment samples were kept cool until they reached Ann Arbor. All samples were then refrigerated in darkness, in sealed containers, until bioassays were performed, usually within 48 hours of collection.

\subsection{Bacterial bioassays}

Bioassays with bacteria were conducted during the 1986 and 1987 field seasons with sediment from the three Trenton Channel stations. These bioassays were conducted with three different protocols: clean versus contaminated sediment, elutriate, and pore water. Metabolism of bacteria was measured by uptake of ${ }^{3} \mathrm{H}$-glucose or ${ }^{3} \mathrm{H}$ adenine (New England Nuclear).

Sediment-water solutions for the clean versus contaminated and elutriate bioassays were pre-
Table 1. Dry weight of sediment as percent of wet weight; mean of two replicates.

$\begin{array}{ll}\text { Lake Michigan } & 52 \\ \text { Monguagon Creek } & 37 \\ \text { Black Lagoon } & 32 \\ \text { Gibraltar Bay } & 26\end{array}$

pared as follows: The prescribed amount (see below) of unprocessed sediment (unscreened) was weighed on an electronic balance to the nearest $0.1 \mathrm{mg}$. Leaves, small twigs and other debris were excluded from the sediment. Sediment was weighed as wet weight in order to keep handling to a minimum after collection. Laboratory analysis showed that wet weight of sediment varied between two and four times oven-dried weight (Table 1). The sediment was then washed into $1000 \mathrm{ml}$ of bioassay water, thoroughly mixed and rapidly dispensed into the bioassay incubation vessels. Incubation vessels consisted of Pyrex-type hard glass 15-ml screw-top test tubes which were sterilized just before use.

The clean versus contaminated sediment bioassays consisted of incubation of four matched pairs of samples per bioassay. One member of each pair received clean (central Lake Michigan) sediment and the other member contaminated sediment from one of the Detroit River stations. One bioassay was conducted for each site for each time period. Bacterial bioassays were completed for all sites (Lake Michigan plus the three Trenton Channel stations) in one day for a given time period. Sediment concentrations were 0,12 , 120 , and $1200 \mathrm{mg} \mathrm{l}^{-1}$ wet weight in 1986; in 1987 a $600 \mathrm{mg} \mathrm{l}^{-1}$ weight was added, and the control was not assayed with a $0 \mathrm{mg} \mathrm{l}^{-1}$ 'contaminated' matched pair.

The sterile test tubes were filled with $15 \mathrm{ml}$ of sediment-water solution. These samples were inoculated with $2 \mu \mathrm{Ci}$ of carrier-free, high-specific activity $(30 \mathrm{Ci} / \mathrm{mmole}){ }^{3} \mathrm{H}$-isotope in $0.2 \mathrm{ml}$ of sterile water. The charge of isotope contained $0.012 \mu \mathrm{g}$ glucose (New England Nuclear - NET 100 ) or $0.016-0.018 \mu \mathrm{g}$ adenine (New England Nuclear - NET 350). Glucose was only used in the first experiments (May-June 1986), with all 
other bioassays in 1986 and 1987 employing ${ }^{3} \mathrm{H}$ adenine. After inoculation, the tubes were immediately tightly capped and wrapped in aluminum foil. Tubes were then placed in an incubator and rotated, at $1 \mathrm{rpm}$ on a $46-\mathrm{cm}$-diameter vertical disk-shaped rotator, to keep sediment in suspension. Samples were incubated for two hours in darkness with the incubator set to the river water temperature.

The elutriate bioassays followed the above protocol except that the isotope was not added immediately after the sediment-water mixture was placed in the test tubes. Rather, the bioassay samples were rotated for 0.5 hour, allowed to settle for one hour, then inoculated with isotope and incubated for two hours in the dark without rotation. The clean sediment from the bioassays described above served as the other half of the matched pair for the elutriate bioassays. The elutriate bioassays were not conducted in 1987.

Pore water was extracted from sediment by centrifuging $250 \mathrm{ml}$ of wet sediment at $2000 \mathrm{rpm}$ for $45 \mathrm{~min}$ and then drawing off the supernatant. Pore water was diluted to concentrations of 0.5 , 1.0 and $10.0 \mathrm{ml}$ of pore water (corresponding to approximately $1.9,3.7$, and $37 \mathrm{~g}$ of sediment, wet weight) per liter bioassay water.

Pore water bioassays followed the same protocol as the clean versus contaminated bioassays after the pore water-river water solution was mixed. The solution was dispensed into the sterile test tubes and the tubes inoculated with $2 \mu \mathrm{Ci}$ of ${ }^{3} \mathrm{H}$ isotope (glucose or adenine). Incubations were conducted in the dark for two hours without rotation. The pore water bioassays were not conducted in 1987.

All bacterial bioassays were conducted in triplicate, three incubation tubes per treatment. The average of the three tubes was considered the response of the bioassay at one sediment concentration at one location. Bacterial bioassays were corrected for instantaneous and abiotic uptake of isotope by subtracting a time zero blank from each uptake value. Time zero blanks were determined by inoculating three test tubes with the 120 or $1200 \mathrm{mg} \mathrm{1}^{-1}$ sediment-water mixture and immediately filtering the samples without any in- cubation period. The amount of radioactive isotope injected into each test tube (standards) was determined by injecting $0.2 \mathrm{ml}$ of isotope and sterile water directly into a scintillation vial.

Immediately after incubation the contents of the test tubes were filtered onto Millipore SA filters $(0.2-\mu$ pore size) with a low vacuum. Each filter was rinsed with five $1-\mathrm{ml}$ aliquots of ice-cold trichloroacetic acid $(5 \% \mathrm{v} / \mathrm{v})$ except for the glucose experiments (May-June 1986) where each filter was rinsed with $5 \mathrm{ml}$ of sterile water. The damp filters were placed into scintillation vials containing $10 \mathrm{ml}$ of Safety-Solve, a water-dispersing cocktail. All samples, standards, and blanks from each bioassay were assayed with a liquid scintillation counter at the same time.

\subsection{Phytoplankton bioassays}

The phytoplankton bioassays used the same overall protocol as the bacterial bioassay. The sediment-water and pore water assay solutions were prepared with the same technique as the bacterial bioassays. The differences between the two bioassays were the use of ${ }^{14} \mathrm{C}$-sodium bicarbonate (New England Nuclear - NEC 086H), larger incubation vessel, incubations in the light and different sediment concentrations in 1987. Results from 1986 showed that sediment concentrations approaching $1200 \mathrm{mg} \mathrm{l}^{-1}$ suppressed uptake of isotope to such an extent that differences between matched pairs were difficult to determine. In 1987 sediment concentrations for phytoplankton bioassays were changed to $75,150,300$, and $600 \mathrm{mg} \mathrm{l}^{-1}$ wet weight.

Phytoplankton bioassays consisted of three 125-ml bottles per sediment weight and type (the bottles actually held $145 \mathrm{ml}$ ). Each triplicate was comprised of two light bottles and one dark bottle. After the bottles were filled with the appropriate solution, $2 \mathrm{ml}$ of incubation water was removed to provide space for the charge of isotope. Two $\mu \mathrm{Ci}$ of ${ }^{14} \mathrm{C}$-sodium bicarbonate in $2 \mathrm{ml}$ water was added to each bottle which was immediately capped. Incubations were conducted in a well-lit incubator $\left(300-500 \mu \mathrm{E} \mathrm{m}^{-2} \mathrm{~s}^{-1}\right)$ which 
was maintained at river water temperature. Samples were rotated for the 4-hour incubation. Elutriate bioassays were conducted by rotating the samples for 0.5 hour, then letting them settle for one hour followed by injecting with the ${ }^{14} \mathrm{C}$ and a 4-hour incubation without rotation. Pore water bioassays were incubated for four hours without rotation. Similar to the bacterial bioassays, only clean versus contaminated bioassays were conducted in 1987 .

The ${ }^{14} \mathrm{C}$ isotope was prepared by using conventional methods in 1986 and ultra-clean metalfree methods in 1987 (Fitzwater et al., 1982). The conventional methods consisted of purchasing $1.0 \mathrm{mCi}$ of bicarbonate ${ }^{14} \mathrm{C}$, diluting the $1.0 \mathrm{ml}$ to $1000 \mathrm{ml}$ with sterile water with the $\mathrm{pH}$ adjusted to approximately 8.5 , and dispensing this solution into glass ampoules which were immediately sealed with a torch. Sealed ampoules were sterilized and stored in a refrigerator until use. The ultra-clean modification of the inoculation procedure consisted of the following: The initial charge of ${ }^{14} \mathrm{C}$ was cut to $100 \mathrm{ml}$ with sterile water which had a $\mathrm{pH}$ of about 8.5 . This $100 \mathrm{ml}$ was then stored in a Teflon bottle in the dark in a refrigerator until the day of bioassay. In the morning before the bioassays began, the stock was cut to working strength by diluting $12 \mathrm{ml}$ of the stored ${ }^{14} \mathrm{C}$ solution to $60 \mathrm{ml}$ with sterile water. This working solution was kept in another Teflon bottle and dispensed with non-metallic pipettes, $1 \mathrm{ml}(2 \mu \mathrm{Ci})$ per incubation bottle.

Bioassays were terminated by removing the bottles from the incubator and placing them in the dark until filtration. Samples were filtered through Millipore HA filters $(0.45 \mu$ pore size) and the damp filters placed in a scintillation vial with $1.0 \mathrm{ml}$ of 10 percent $\mathrm{HCl}$. After a 2-hour soak in the dilute acid to remove carbonates on the filter, $10 \mathrm{ml}$ of water-dispersing scintillation cocktail was added.

The dark bottle of the triplicate incubation was taken to represent non-photosynthetic uptake of ${ }^{14} \mathrm{C}$. The dark uptake was subtracted from the uptake of the two light bottles. The amount of ${ }^{14} \mathrm{C}$ reaching the samples was determined by injecting one charge $(1.0 \mathrm{ml})$ into a scintillation vial contain- ing $10 \mathrm{ml}$ of cocktail and $1.0 \mathrm{ml}$ of scintillationgrade phenethylamine. The latter substance was used to keep the ${ }^{14} \mathrm{C}$ trapped in the vial by preventing any ${ }^{14} \mathrm{CO}_{2}$ from escaping from solution.

The uptake of the samples was converted to units of uptake of $\mu \mathrm{g} \mathrm{Cl}^{-1} \mathrm{~h}^{-1}$ which required the determination of alkalinity in the Detroit River water. The alkalinity determination was made by mixing $20.0 \mathrm{ml}$ of sample with $5.0 \mathrm{ml}$ of $0.010 \mathrm{~N}$ $\mathrm{HCl}$ and measuring the $\mathrm{pH}$ of the resultant mixture.

\subsection{Isotope assays}

Activity of samples with ${ }^{3} \mathrm{H}$ and ${ }^{14} \mathrm{C}$ was determined with a Beckman LS 7500 liquid scintillation counter. Each type of isotope was measured with a separate program which optimized counting efficiency by an external standard and Compton Edge. Samples were counted for up to 10 minutes or until the standard error of counting efficiency fell below 2 percent of the mean counts per minute. Counts per minute for each sample were converted to disintegrations per minute by external standards, a quench curve, and $\mathrm{H}$ numbers. The quench curve was determined by counting external quenched standards of known specific activity.

\subsection{Biomass estimates}

At the time of each bacterial bioassay, 5-ml samples were taken from all sediment-water concentrations, preserved with one drop of glutaraldehyde, and stored in a refrigerator. Within a few weeks bacteria samples were processed for acridine orange direct counts using a modification (Moll \& Brahce, 1986) of the technique of Hobbie et al. (1977). A Leitz Wetzlar Dialux 20 microscope was used to count bacteria, at a magnification of $787 \times$ or $1250 \times$. Bacteria were counted in 6 to 10 fields of view, depending on variability of the counts.

During each algal bioassay, water from each sediment-water type and concentration was fil- 
tered for chlorophyll measurement, using methods based on those in Davis \& Simmons (1979). Chlorophyll measurements involved collection of algae on a Whatman GF/C filter, initial extraction in 90 percent acetone buffered with magnesium carbonate, and further extraction by grinding. The amount of chlorophyll in the sample was estimated with a Turner Designs Model 10 fluorometer. The fluorometer was calibrated by taking measurements of known dilutions of $1 \mathrm{~g}$ chlorophyll $a$. These same dilutions were also measured with a Beckman spectrophotometer. Chlorophyll equations were obtained from Strickland \& Parsons (1972).

\subsection{Statistical analyses}

All statistical techniques described below were conducted with the Michigan Interactive Data Analysis System (MIDAS) and BMDP Statistical Software (Fox \& Guire, 1976; Dixon et al., 1981). Clean versus contaminated sediment bioassays were analyzed using two-factor Analysis of Variance (ANOVA) where the main effects were sediment type (clean or contaminated, or site from which sediment was collected) and concentration of sediment. Elutriate bioassay results were contrasted with clean and contaminated sediment results using two-factor ANOVA, where the main effects were sediment concentration and experimental treatment. A one-factor ANOVA contrasted the four pore water concentrations. Levene's Test for equality of variances was conducted for all two-factor ANOVAs and for pore water assays (Brown \& Forsythe, 1974). The Brown-Forsythe Test, similar to ANOVA but less sensitive to violations of the assumptions of parametric analysis, was also used for all bioassay results. In those instances where the Levene's Test indicated that intergroup variances were not homogeneous, the Brown-Forsythe Test was considered the more reliable form of analysis. Otherwise, the ANOVA results were viewed as the definitive statistical analysis.

\section{Results}

\subsection{Bacterial bioassays}

\subsubsection{Clean versus contaminated sediment bio- assays}

The clean versus contaminated sediment bioassays comprised the major portion of the bacterial studies in 1986 and 1987. This strategy was adopted on the basis of 1986 studies where these types of bioassays were found to yield reproducible results. Consistent results were observed despite a change in substrates from glucose to adenine during 1986 and adjustment to techniques between 1986 and 1987.

During 1986, the uptake of substrate for the clean versus contaminated sediment bioassay showed a pattern with relatively constant uptake among the four different clean sediment concentrations. The average of three sets of bioassays showed a reduction in uptake of about 20 percent between the 0 and $1200 \mathrm{mg} \mathrm{l}^{-1}$ clean sediment concentrations. In contrast, bioassays with contaminated sediments showed a large suppression of uptake, typically about 50 percent between the 0 and $1200 \mathrm{mg} \mathrm{l}^{-1}$ sediment concentrations. These trends were generally observed throughout 1986 but differed among the three sampling locations.

The results of the bacterial bioassays were transformed into units of uptake adjusted for biomass. The rationale for this transformation was that the sediment additions significantly increased bacterial biomass. The resultant increase in bacterial numbers caused a subsequent increase in uptake which could mask the suppression of isotope uptake by the contaminated materials. The transformation yielded units of picograms per hour per million cells $\left(\mathrm{pg} \mathrm{h}^{-1} \mathrm{M}^{-1}\right.$ cells), which are referred to as adjusted uptakes.

Adjusted uptake results from the 1986 bioassays showed a decline in uptake with both clean and contaminated sediment additions. Suppression of uptake of glucose and adenine with clean sediment ranged from 34.3 to 52.0 percent (Table 2). Suppression of uptake with contaminated sediment ranged from 65.2 to 79.2 percent 
Table 2. Bacteria uptake adjusted for biomass $\left(\mathrm{pg} \mathrm{h}^{-1} \mathrm{M}^{-1}\right.$ cells) at various concentrations of sediment from Lake Michigan (Clean), Monguagon Creek (MC), Black Lagoon (BL), and Gibraltar Bay (GB), pooled over all months, 1986.

\begin{tabular}{llccc}
\hline \multirow{2}{*}{ Site } & \multicolumn{4}{l}{ Sediment concentration $\left(\mathrm{mg} \mathrm{l}^{-1}\right)$} \\
\cline { 2 - 5 } & 0 (control) & 12 & 120 & 1200 \\
\hline Clean & 17.2 & 21.1 & 22.8 & 11.3 \\
Contam: MC & 12.3 & 15.7 & 16.1 & 4.28 \\
Elutriate: MC & 24.6 & 17.3 & 16.2 & 5.53 \\
Clean & 27.7 & 21.9 & 33.2 & 13.3 \\
Contam: BL & 27.6 & 30.6 & 10.6 & 5.73 \\
Elutriate: BL & 20.1 & 22.8 & 8.02 & 2.16 \\
Clean & & & & \\
Contam: GB & 20.0 & 20.9 & 17.3 & 13.5 \\
Elutriate: GB & 33.7 & 26.7 & 29.6 & 5.83 \\
\hline
\end{tabular}

(Table 2). This pattern of suppression of adjusted uptake with increasing sediment concentration was observed in every set of bioassays except the May-June experiments using Monguagon Creek sediment and August using clean (Lake Michigan) sediment.

The 1987 studies were modified based on the results of the 1986 experiments. The clean versus contaminated sediment bioassay became the primary mechanism of investigating the effects of Trenton Channel sediments on bacteria in 1987. Bioassays were conducted once per month from April through October inclusive. The basic format of the bioassay remained unchanged although an additional sediment concentration of $600 \mathrm{mg}^{-1}$ was added while the $0 \mathrm{mg} 1^{-1}$ concentration was viewed as the no-sediment control for both the clean and contaminated bioassays.

The uptake of adenine by bacteria followed a somewhat different pattern in 1987 compared to the 1986 results. Both years had similar trends for bioassays with clean sediment; uptake remained relatively constant among all sediment concentrations. Bioassays with contaminated sediment showed an increase in uptake with seasonal averages of 9.31 and $17.21 \mathrm{ng}^{-1} \mathrm{~h}^{-1}$ for 0 and $1200 \mathrm{mg} \mathrm{l}^{-1}$ of sediment respectively. The trend in uptake of adenine was relatively uniform
Table 3. Bacteria uptake adjusted for biomass ( $\mathrm{pg} \mathrm{h}^{-1} \mathrm{M}^{-1}$ cells) at various concentrations of sediment from Lake Michigan and Trenton Channel sites, pooled over all months, 1987.

\begin{tabular}{llllll}
\hline Site & \multicolumn{5}{c}{ Sediment concentration $\left(\mathrm{mg} \mathrm{l}^{-1}\right)$} \\
\cline { 2 - 6 } & $0($ control $)$ & 12 & 120 & 600 & 1200 \\
\hline Lake Michigan & 9.81 & 6.11 & 7.02 & 5.68 & 4.75 \\
Monguagon Creek & 9.81 & 7.12 & 5.14 & 4.55 & 3.76 \\
Black Lagoon & 9.81 & 7.02 & 5.52 & 2.46 & 2.27 \\
Gibraltar Bay & 9.81 & 6.31 & 6.83 & 3.42 & 3.27 \\
\hline
\end{tabular}

among the three sampling sites. Uptake was slightly lower at Gibraltar Bay than the other two locations. These patterns of uptake for both clean and contaminated sediment were observed for all 1987 bioassays.

Despite the increase in uptake with contaminated sediment from the 1987 bioassays, when uptake was adjusted for bacterial biomass, the patterns followed those observed in 1986 (Table 3). Average adjusted uptake for 1987 for the clean sediment bioassays declined from 9.81 to $4.75 \mathrm{pg} \mathrm{h}^{-1} \mathrm{M}^{-1}$ cells, as clean sediment concentrations increased from 0 to $1200 \mathrm{mg}^{-1}$ (Table 3). For a similar increase in contaminated sediments, average adjusted uptake declined from 9.81 to $3.10 \mathrm{pg} \mathrm{h}^{-1} \mathrm{M}^{-1}$ cells. These trends of decline in adjusted uptake with increasing sediment concentrations were observed at all three locations for most bioassays. Also, in all but 2 of 21 sets of experiments, the suppression of adjusted uptake was greater for the contaminated sediments than the clean sediments. Figures 2 and 3 show examples of the 1987 experiments with adjusted uptake for increasing sediment additions and differences between adjusted and unadjusted uptake results for one location, respectively.

The similarities of results from 1986 and 1987 were striking considering that the method changed between years and the experiments were conducted on natural bacteria populations which were not preconditioned to the substrate. Experiments conducted in 1986 showed a decline in the average adjusted uptake of 41 and 75 percent 


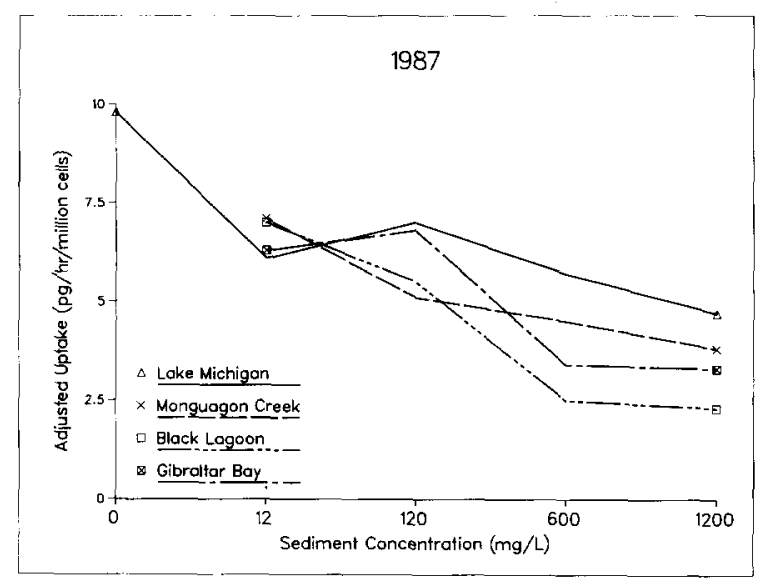

Fig. 2. Average $1987{ }^{3} \mathrm{H}$ uptake adjusted for bacteria biomass. Each observation is the mean of 21 incubations.

from 0 to $1200 \mathrm{mg} \mathrm{l}^{-1}$ for clean and contaminated sediment, respectively. Likewise, the same averages from 1987 showed a decline of 51 and 67 percent for clean and contaminated sediment, respectively. Further, these patterns were repeated for most bioassays in both years. The key to reproducing and understanding the bioassays appears to arise from transforming the uptake values to adjusted uptake values, i.e., correcting for biomass.

While the results from the clean versus contaminated experiments provided many useful inferences, the overall experimental design also con-

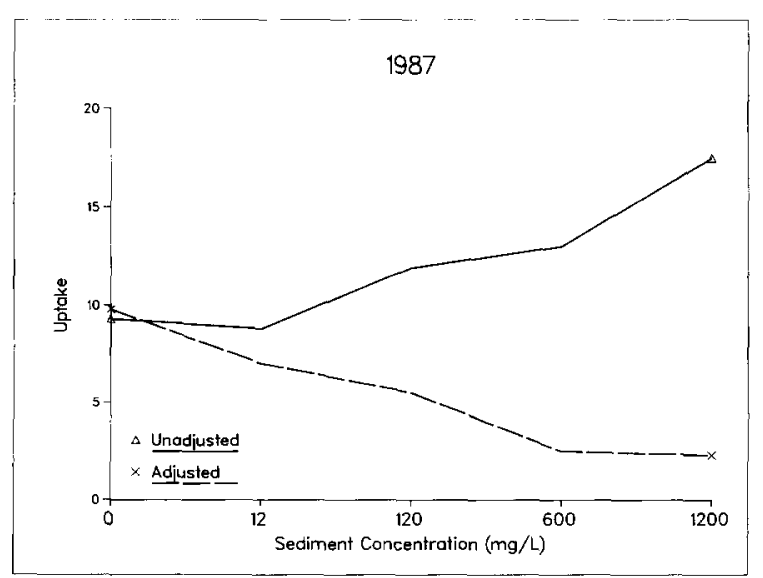

Fig. 3. Black Lagoon average $1987{ }^{3} \mathrm{H}$ uptake, adjusted and unadjusted for bacteria biomass. Each observation is the mean of 21 incubations. formed to a specific statistical model. A twofactor ANOVA was used to test two hypotheses: that uptake levels were significantly affected by sediment concentration (from 0 to $1200 \mathrm{mg} \mathrm{l}^{-1}$ ), and that uptake levels were significantly affected by sediment type (clean or contaminated). Two different types of ANOVAs are presented in each table, the conventional parametric analysis and a modified version called the Brown-Forsythe ANOVA. The latter form has less restrictive assumptions because the equality of within-group variances is not required (Dixon et al., 1981). Generally, the Brown-Forsythe ANOVAs are more conservative than their parametric counterparts. Because more often than not the assumption of equality of variances was met (tested with Levene's Statistic), the results discussed below refer only to the regular parametric ANOVA. The Brown-Forsythe results are presented in every case as a comparison to the regular analysis.

The ANOVAs from 1986 were conducted on each of the three sites for each of three months for a total of nine analyses (Table 4). Two out of nine

Table 4. Summary of ANOVAs for 1986 bacteria clean versus contaminated sediment bioassays, uptake rates adjusted for biomass.

\begin{tabular}{|c|c|c|c|c|c|c|c|}
\hline \multirow{2}{*}{\multicolumn{2}{|c|}{$\begin{array}{l}\text { Site and } \\
\text { Date }\end{array}$}} & \multicolumn{3}{|c|}{ Standard ANOVA } & \multicolumn{3}{|c|}{ Brown-Forsythe } \\
\hline & & Treat & Conc & Int & Treat & Conc & Int \\
\hline \multicolumn{2}{|c|}{ MC, May } & $* *$ & $*$ & ns & ns & ns & ns \\
\hline \multicolumn{2}{|c|}{ BL, June } & ns & $* *$ & $* *$ & ns & ns & ns \\
\hline \multicolumn{2}{|c|}{ GB, June } & ns & $* *$ & ns & ns & $* *$ & ns \\
\hline \multicolumn{2}{|c|}{ MC, August } & ns & ns & ns & ns & ns & ns \\
\hline \multicolumn{2}{|c|}{ BL, August } & ns & $* *$ & $* *$ & ns & $*$ & $* *$ \\
\hline \multicolumn{2}{|c|}{ GB, August } & ns & $* *$ & ns & ns & $*$ & ns \\
\hline \multicolumn{2}{|c|}{ MC, October } & ns & ns & ns & ns & ns & ns \\
\hline \multicolumn{2}{|c|}{ BL, October } & $\mathrm{ns}$ & $* *$ & $* *$ & ns & $* *$ & $* *$ \\
\hline \multicolumn{2}{|c|}{ GB, October } & $* *$ & $* *$ & $* *$ & $* *$ & $* *$ & $* *$ \\
\hline * & \multicolumn{7}{|c|}{$=$ significant at 0.01} \\
\hline$* *$ & \multicolumn{7}{|c|}{$=$ significant at 0.001} \\
\hline & \multicolumn{7}{|c|}{$=$ not significant } \\
\hline Treat & \multicolumn{4}{|c|}{$\begin{aligned}= & \text { experimental treatment, } \\
& \text { Int }=\text { interaction. }\end{aligned}$} & \multicolumn{3}{|c|}{ Conc $=$ concentration, } \\
\hline MC & \multicolumn{2}{|c|}{$=$ Monguagon } & $\begin{array}{l}\text { Creek } \\
\text { ar Bay. }\end{array}$ & & $\mathrm{BL}=\mathrm{Blacl}$ & \multicolumn{2}{|c|}{ Lagoon, } \\
\hline
\end{tabular}


Table 5. Summary of ANOVAs for 1987 bacteria clean versus contaminated sediment bioassays, uptake rates adjusted for biomass.

\begin{tabular}{|c|c|c|c|c|c|c|}
\hline \multirow[t]{2}{*}{ Date } & \multicolumn{3}{|c|}{ Standard ANOVA } & \multicolumn{3}{|c|}{ Brown-Forsythe } \\
\hline & Treat & Conc & Int & Treat & Conc & Int \\
\hline April & ns & ns & $\mathrm{ns}$ & $\mathrm{ns}$ & ns & ns \\
\hline May & $* *$ & $* *$ & $* *$ & ns & ns & ns \\
\hline June & $* *$ & $* *$ & $*$ & $*$ & $* *$ & $*$ \\
\hline July & $* *$ & $* *$ & ns & $*$ & $* *$ & ns \\
\hline August & $* *$ & $* *$ & $* *$ & $* *$ & $* *$ & $*$ \\
\hline September & $* *$ & $* *$ & $*$ & $* *$ & $* *$ & ns \\
\hline October & ns & $* *$ & ns & ns & $*$ & ns \\
\hline
\end{tabular}

$$
\begin{aligned}
* & =\text { significant at } 0.01 \\
* * \quad & \text { significant at } 0.001 \\
\mathrm{~ns} \quad & \text { not significant } \\
\text { Treat }= & \text { experimental treatment, Conc = concentration, } \\
& \text { Int }=\text { interaction. }
\end{aligned}
$$

analyses showed significant effects due to substrate type and seven out of nine were significant for sediment concentration. Four interactions were significant for the adjusted uptake results.

The experimental design shifted slightly in 1987 with one ANOVA used to analyze data for all three sites plus the clean sediment. This resulted in seven ANOVAs, one for each set of experiments each month (Table 5). Results from the ANOVAs with adjusted uptake results showed significant effects from sediment concentration for six out of seven analyses and four significant interactions. Five out of seven ANOVAs showed significant effects due to sediment type. The increase in the number of statistically significant treatment effects for sediment type for 1987 appeared to arise from a reduction in the withingroup variance (among replicate incubations) between the two years.

\subsubsection{Elutriate bioassays}

Patterns of uptake for the elutriate bioassays matched those of the clean versus contaminated experiments. Average unadjusted uptakes declined almost 60 percent from 48.3 to $20.2 \mathrm{ng} \mathrm{l}^{-1} \mathrm{~h}^{-1}$ as Black Lagoon sediment concentrations increased from 0 to $1200 \mathrm{mg} \mathrm{l}^{-1}$. Likewise,
Monguagon Creek unadjusted uptakes declined 51 percent and Gibraltar Bay uptakes 54 percent. When adjusted for bacterial biomass, reductions in 1986 average uptakes were 77 percent for Monguagon Creek, 89 percent for Black Lagoon, and 65 percent for Gibraltar Bay (Table 2). These same trends were observed for almost every elutriate experiment conducted in 1986.

The statistical significance of sediment concentration and type for the elutriate experiments was tested with two-factor ANOVA. As with the clean versus contaminated experiments, nine ANOVAs were conducted, one for each of three sampling locations and each of three field trips. In these analyses, sediment type was actually a contrast between the contaminated elutriate bioassay and the Lake Michigan sediment from the clean versus contaminated experiments. The ANOVAs showed that for adjusted uptake, six of nine experiments had significant effects due to sediment type and six of nine for sediment concentration (Table 6). Five of the nine ANOVAs had significant interaction terms.

Table 6. Summary of ANOVAs for 1986 bacteria elutriate versus clean sediment bio assays, uptake rates adjusted for biomass.

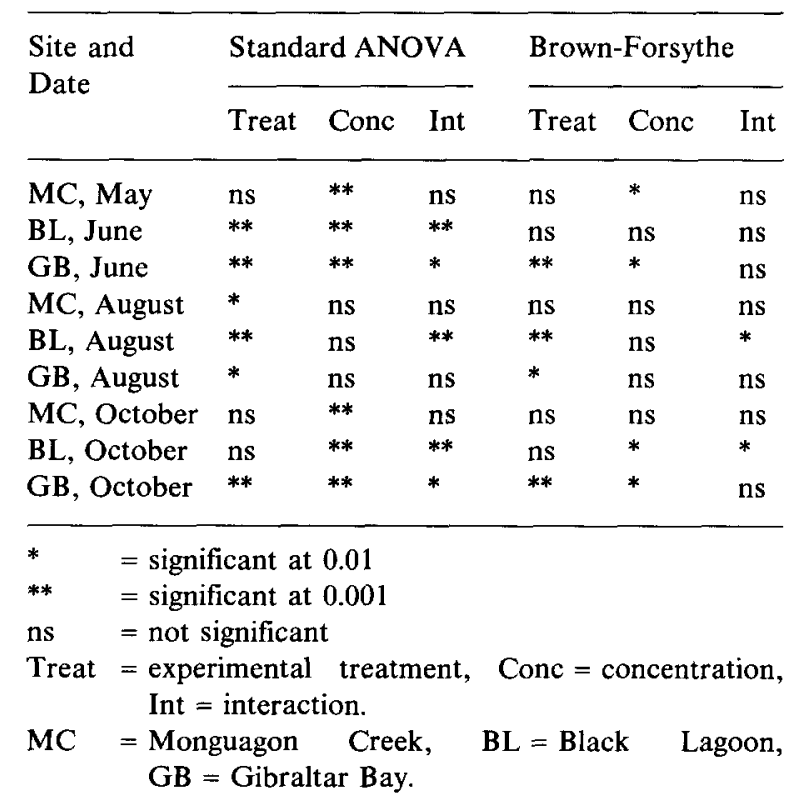




\subsubsection{Pore water bioassays}

Bioassays using pore water were intended to determine if the locus of toxicity was the pore water alone or bulk sediment. The results showed that the pore water was much less toxic than bulk sediment. The results of the pore water bioassays were uneven with some suppression, enhancement, and unchanged rates of uptake (Table 7). The levels of bacterial biomass remained relatively constant with the addition of pore water; at two locations the amount of pore water added to the river water had little effect on bacterial abundances, while at Gibraltar Bay the biomass almost doubled.

There was no consistent trend in the uptake of substrate in bioassays using pore water. At Monguagon Creek, the addition of pore water stimulated uptake, while at Black Lagoon and Gibraltar Bay the pore water suppressed uptake (Table 7). The patterns were relatively unchanged after the uptake rates were adjusted for biomass. The bioassays from three different locations yielded three different results. Uptake at Monguagon Creek was highly stimulated by the addition of pore water, remained unchanged at

Table 7. Bacteria biomass (million cells $\mathrm{ml}^{-1}$ ), uptake (ng $\mathrm{I}^{-1} \mathrm{~h}^{-1}$ ), and uptake adjusted for biomass $\left(\mathrm{pg} \mathrm{h}^{-1} \mathrm{M}^{-1}\right.$ cells) at various concentrations of pore water from Trenton Channel sites, pooled over all months, 1986.

\begin{tabular}{llccc}
\hline Site & \multicolumn{3}{l}{ Pore water concentration $\left(\mathrm{ml} \mathrm{1}^{-1}\right)$} \\
\cline { 2 - 5 } & 0 (control) & 0.5 & 1.0 & 10.0 \\
\hline Biomass & & & & \\
Monguagon Creek & 2.20 & 2.15 & 2.33 & 2.15 \\
Black Lagoon & 1.73 & 1.98 & 2.78 & 2.09 \\
Gibraltar Bay & 2.58 & 4.00 & 3.09 & 4.57 \\
& & & & \\
Uptake & & & & \\
Monguagon Creek & 27.4 & 24.7 & 17.3 & 29.1 \\
Black Lagoon & 44.0 & 34.9 & 35.1 & 30.1 \\
Gibraltar Bay & 58.6 & 32.4 & 28.8 & 27.8 \\
& & & & \\
Adjusted uptake & & & & \\
Monguagon Creek & 12.3 & 20.7 & 13.0 & 33.2 \\
Black Lagoon & 24.8 & 19.7 & 14.4 & 20.6 \\
Gibraltar Bay & 22.5 & 20.1 & 20.0 & 9.27 \\
\hline
\end{tabular}

Black Lagoon, and was suppressed at Gibraltar Bay.

\subsection{Phytoplankton bioassays}

\subsubsection{Clean versus contaminated sediment bio- assays}

Phytoplankton were extremely sensitive to the addition of sediment to the bioassay water. Uptake of ${ }^{14} \mathrm{C}$ by phytoplankton, unadjusted for biomass, showed approximately a linear decrease with increasing concentration of sediment.

Increasing chlorophyll concentrations with addition of sediment indicated Trenton Channel sediment contained algae. Because higher biomass could increase uptake and thus mask the effect of contaminated sediment, uptake rates were adjusted by dividing by chlorophyll concentrations. Uptake adjusted for biomass showed a somewhat more complex pattern than unadjusted uptake. Averaged over all months and sites, adjusted uptake also declined with concentration, but in a less linear fashion than unadjusted uptake. During 1986, two sites had approximately the same average adjusted uptake, while Gibraltar Bay uptakes were about 30 percent higher (Table 8). The results show a reduction in uptake

Table 8. Phytoplankton uptake adjusted for biomass ( $\mu \mathrm{g}^{14} \mathrm{C} \mathrm{h}^{-1} \mu \mathrm{g}^{-1}$ chlorophyll- $\alpha$ ) at various concentrations of sediment from Lake Michigan (Clean), Monguagon Creek (MC), Black Lagoon (BL), and Gibraltar Bay (GB), pooled over all months, 1986.

\begin{tabular}{lcccc}
\hline \multirow{2}{*}{ Site } & \multicolumn{4}{c}{ Sediment concentration $\left(\mathrm{mg} \mathrm{1}^{-1}\right)$} \\
\cline { 2 - 5 } & $0($ control $)$ & 12 & 120 & 1200 \\
\hline Clean & 15.1 & 14.2 & 8.3 & 2.2 \\
Contam: MC & 14.1 & 12.9 & 8.4 & 1.7 \\
Elutriate: MC & 15.6 & 10.8 & 6.9 & 0.7 \\
& & & & \\
Clean & 22.5 & 15.8 & 12.9 & 1.8 \\
Contam: BL & 16.1 & 16.4 & 5.2 & 0.4 \\
Elutriate: BL & 14.4 & 10.2 & 4.6 & 0.5 \\
& & & & \\
Clean & 19.7 & 17.8 & 13.8 & 2.2 \\
Contam: GB & 23.2 & 16.5 & 9.7 & 1.7 \\
Elutriate: GB & 8.2 & 14.8 & 7.1 & 0.9 \\
\hline
\end{tabular}




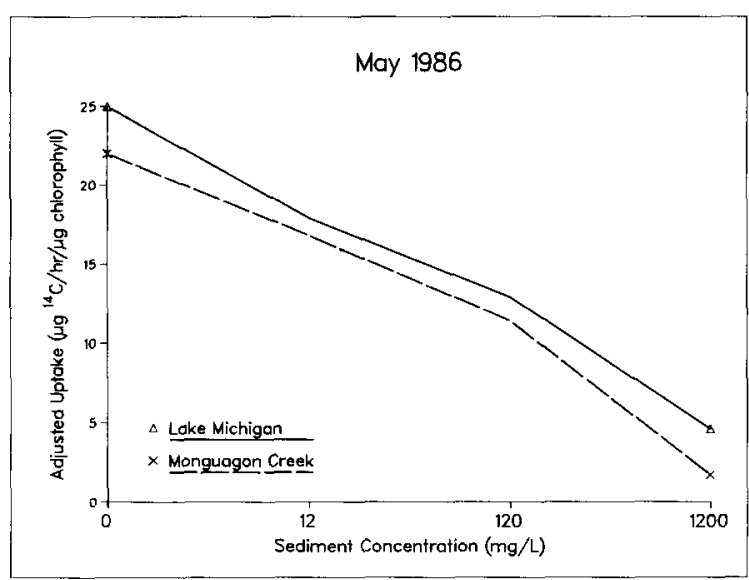

Fig. 4. Phytoplankton uptake adjusted for biomass, May and June 1986. Each observation is the mean of 2 incubations.

at all concentrations of sediment. Uptake was reduced approximately 15 percent for clean and contaminated sediment at low concentrations (12 $\mathrm{mg}^{-1}$ - Table 8). The reduction was about 40 percent for the clean sediment and 56 percent for the contaminated sediment at $120 \mathrm{mg} \mathrm{l}^{-1}$, and 89 and 93 percent at $1200 \mathrm{mg} \mathrm{l}^{-1}$ for clean and contaminated sediment, respectively (Table 8 ). Figure 4 shows the trend in uptake with increasing sediment for two locations for the May 1986 bioassay.

Because of the extreme suppression of uptake at the sediment concentration of $1200 \mathrm{mg} \mathrm{l}^{-1}$, in 1987 the highest concentration was changed to $600 \mathrm{mg} \mathrm{l}^{-1}$ and intermediate concentrations were adjusted to 75,150 , and $300 \mathrm{mg} \mathrm{l}^{-1}$. For 1987 , uptake adjusted for biomass dropped approximately 50 percent from 0 to $600 \mathrm{mg} \mathrm{l}^{-1}$ (Table 9). The biggest drop in adjusted uptake occurred between 75 and $150 \mathrm{mg} \mathrm{l}^{-1}$ added sediment (Table 9).

During both 1986 and 1987, there was some variation among, and sometimes within, bioassays in both rates of unadjusted uptake and uptake adjusted for biomass. Some individual treatment groups in the bioassays showed results contrary to the general trends of reduced uptake with increasing sediment concentration, while other bioassays expressed the trends intensely.
Table 9. Phytoplankton uptake adjusted for biomass ( $\mu \mathrm{g}^{14} \mathrm{Ch}^{-1} \mu \mathrm{g}^{-1}$ chlorophyll- $\alpha$ ) at various concentrations of sediment from Lake Michigan and Trenton Channel sites, pooled over all months, 1987.

\begin{tabular}{lllllr}
\hline Site & \multicolumn{6}{l}{ Sediment concentration $\left(\mathrm{mg} \mathrm{l}^{-1}\right)$} \\
\cline { 2 - 6 } & $\begin{array}{l}0 \\
\text { (control) }\end{array}$ & 75 & 150 & 300 & 600 \\
& & & & & \\
\hline Lake Michigan & 21.0 & 23.4 & 19.3 & 17.5 & 14.6 \\
Monguagon Creek & 21.0 & 31.1 & 21.6 & 14.9 & 8.7 \\
Black Lagoon & 21.0 & 19.2 & 15.5 & 8.8 & 5.2 \\
Gibraltar Bay & 21.0 & 34.7 & 22.7 & 18.4 & 14.1
\end{tabular}

Two-factor ANOVA was used to test the hypothesis that uptake rates were not significantly affected by sediment concentration or sediment type (site from which sediment came). In 1986 bioassays, uptake adjusted for biomass was always significantly different among sediment concentrations and was significantly different between sediment types for four out of nine bioassays (Table 10). Interactions were significant for five out of the nine ANOVAs. In both 1986

Table 10. Summary of ANOVAs for 1986 phytoplankton clean versus contaminated sediment biossays, uptake rates adjusted for biomass.

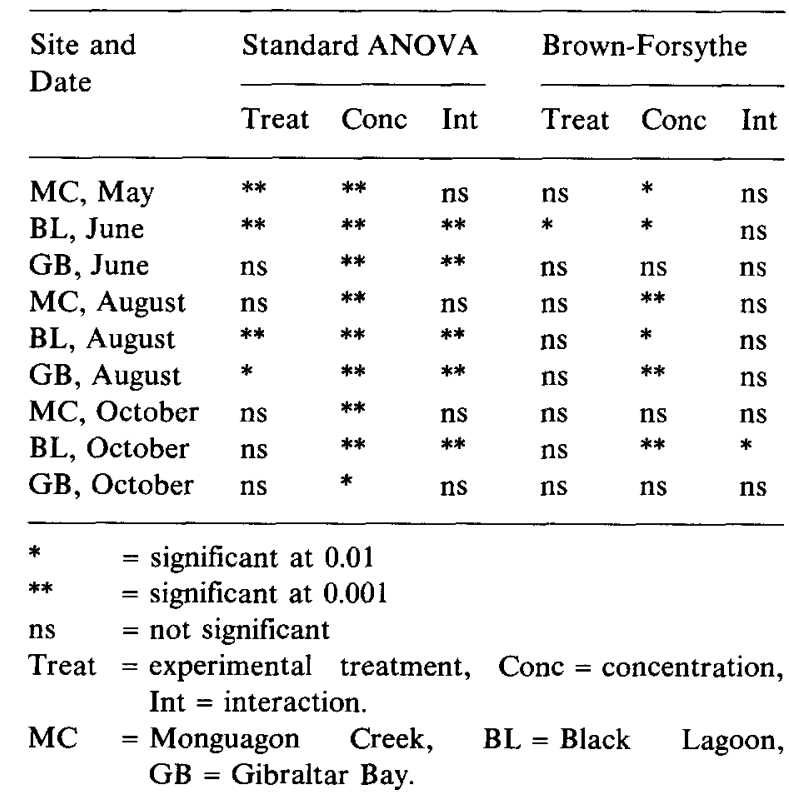


and 1987, significant interactions were usually due to large uptake differences between sediment types at one or two concentrations and not at other concentrations.

The experimental design used in the 1987 studies permitted direct comparison among all three Trenton Channel sites and Lake Michigan sediment. Pairwise t-tests showed that Gibraltar Bay uptake rates were often higher, and Black Lagoon uptake often lower, than uptake at other sites for a given concentration of sediment. Uptake not adjusted for biomass was always significantly different (ANOVA) among sediment concentrations, and was significantly different among sites in four of seven months. Uptake adjusted for biomass similarly was always significantly different among sediment concentrations, and was significantly different among sites in five of seven months (Table 11). Four interactions were significant for adjusted uptake (Table 11). For the June and August bioassays, adjusted uptake was notably different in one cell (Lake Michigan $300 \mathrm{mg} \mathrm{1}^{-1}$ and Monguagon Creek $75 \mathrm{mg} \mathrm{l}^{-1}$, respectively), causing significant interactions. Brown-Forsythe tests revealed a pattern similar to the standard ANOVA, but with a somewhat lower level of significance (Table 11).

Table 11. Summary of ANOVAs for 1987 phytoplankton clean versus contaminated sediment bioassays, uptake rates adjusted for biomass.

\begin{tabular}{|c|c|c|c|c|c|c|}
\hline \multirow{2}{*}{$\begin{array}{l}\text { Site and } \\
\text { Date }\end{array}$} & \multicolumn{3}{|c|}{ Standard ANOVA } & \multicolumn{3}{|c|}{ Brown-Forsythe } \\
\hline & Treat & Conc & Int & Treat & Conc & Int \\
\hline April & $* *$ & $* *$ & ns & ns & ns & ns \\
\hline May & $* *$ & $* *$ & $* *$ & $* *$ & $* *$ & $* *$ \\
\hline June & $* *$ & $* *$ & $* *$ & $*$ & $* *$ & * \\
\hline July & ns & * & ns & ns & ns & ns \\
\hline August & $* *$ & $* *$ & * & $* *$ & $* *$ & ns \\
\hline September & $* *$ & $* *$ & $*$ & ns & * & ns \\
\hline October & ns & $* *$ & ns & ns & $*$ & ns \\
\hline
\end{tabular}

\footnotetext{
* = significant at 0.01

** $\quad=$ significant at 0.001

ns $\quad=$ not significant

Treat $=$ experimental treatment, Conc $=$ concentration, Int $=$ interaction.
}

\subsubsection{Elutriate bioassays}

The elutriate bioassays yielded results similar to the clean versus contaminated sediment bioassays. Uptake of ${ }^{14} \mathrm{C}$ adjusted for biomass was slightly reduced (about $6 \%$ ) at the $12 \mathrm{mg} \mathrm{l}^{-1}$ sediment concentration, substantially reduced $(51 \%)$ at the $120 \mathrm{mg} \mathrm{l}^{-1}$ concentration, and severely reduced $(94 \%)$ at the $1200 \mathrm{mg} \mathrm{l}^{-1}$ concentration (Table 8). These results show the extreme sensitivity of the algae to the incorporation of sediment in the incubation even if that sediment is allowed to settle out of the incubation water.

Two-factor ANOVA was used to test the hypothesis that uptake was not significantly different among concentrations or treatments, where treatment refers to rotated clean sediment, rotated contaminated sediment, or non-rotated contaminated sediment (elutriate). All of the nine standard ANOVAs showed significant differences in both unadjusted and adjusted uptake among sediment concentrations (Table 12). Most BrownForsythe tests (seven of nine for unadjusted uptake, six of nine for adjusted uptake) also showed uptakes were significantly different among sediment concentrations. However, only four BrownForsythe ANOVAs out of nine showed significant

Table 12. Summary of ANOVAs for 1986 phytoplankton elutriate versus clean versus contaminated sediment bioassays, uptake rates adjusted for biomass.

\begin{tabular}{|c|c|c|c|c|c|c|}
\hline \multirow{2}{*}{$\begin{array}{l}\text { Site and } \\
\text { Date }\end{array}$} & \multicolumn{3}{|c|}{ Standard ANOVA } & \multicolumn{3}{|c|}{ Brown-Forsythe } \\
\hline & Treat & Conc & Int & Treat & Conc & Int \\
\hline MC, May & $* *$ & $* *$ & $*$ & $* *$ & $* *$ & ns \\
\hline BL, June & $* *$ & $* *$ & $* *$ & $* *$ & $* *$ & $*$ \\
\hline GB, June & $* *$ & $* *$ & $* *$ & $*$ & $*$ & ns \\
\hline MC, August & ns & $* *$ & ns & ns & $* *$ & ns \\
\hline BL, August & $* *$ & $* *$ & $* *$ & $*$ & $* *$ & ns \\
\hline GB, August & ns & $* *$ & $*$ & ns & ns & ns \\
\hline MC, October & ns & $* *$ & ns & ns & $\mathrm{ns}$ & ns \\
\hline BL, October & $* *$ & $* *$ & $* *$ & ns & $*$ & ns \\
\hline GB, October & ns & $* *$ & ns & ns & ns & ns \\
\hline \\
\hline \multirow{2}{*}{\multicolumn{7}{|c|}{$\begin{array}{ll}* & =\text { significant at } 0.01 \\
* * & =\text { significant at } 0.001 \\
\mathrm{~ns} & =\text { not significant }\end{array}$}} \\
\hline & & & & & & \\
\hline $\begin{array}{r}\text { Treat }=\text { exper } \\
\text { Int }=\end{array}$ & mental & treatn & & \multicolumn{3}{|c|}{ Conc $=$ concentration } \\
\hline
\end{tabular}


differences in adjusted uptake between experimental treatments (Table 12). Five standard ANOVAs were likewise significant. Six of the nine standard ANOVAs had significant interaction terms.

\subsubsection{Pore water bioassays}

The addition of up to 1 percent $v / v$ pore water had little effect on the uptake of ${ }^{14} \mathrm{C}$ by phytoplankton (Table 13), in contrast to the incubations using sediment, which showed a very large reduction in the amount of uptake with increasing amounts of sediment. The only pore water bioassay that showed significant differences in uptake among concentrations was Black Lagoon in October. Pairwise comparisons showed that unadjusted uptake was significantly higher for controls than for treatments, and that 0.5 and $1 \mathrm{ml} \mathrm{l}^{-1}$ samples had higher adjusted uptake than 0 or $10 \mathrm{ml}^{-1}$.

\subsection{Sensitivity, accuracy, and precision of methods}

Bioassays reported in this study were relatively sensitive measures of toxicity, as a small amount of sediment yielded a large reduction in uptake.

Table 13. Phytoplankton biomass ( $\mu \mathrm{g}$ chlorophyll- $\alpha \mathrm{l}^{-1}$ ), uptake $\left(\mu \mathrm{g}^{14} \mathrm{C}^{-1} \mathrm{~h}^{-1}\right)$, and uptake adjusted for biomass ( $\mu \mathrm{g}^{14} \mathrm{Ch}^{-1} \mu \mathrm{g}^{-1}$ chlorophyll- $\alpha$ ) at various concentrations of pore water from Trenton Channel sites, pooled over all months, 1986.

\begin{tabular}{lllll}
\hline Site & \multicolumn{4}{c}{ Pore water concentration $\left(\mathrm{ml} \mathrm{l}^{-1}\right)$} \\
\cline { 2 - 5 } & $0($ control $)$ & 0.5 & 1.0 & 10.0 \\
\hline Biomass & & & & \\
Monguagon Creek & 1.88 & 1.80 & 1.95 & 2.04 \\
Black Lagoon & 1.06 & 0.60 & 0.60 & 0.67 \\
Gibraltar Bay & 0.67 & 0.72 & 0.64 & 0.65 \\
& & & & \\
Uptake & & & & \\
Monguagon Creek & 30.5 & 29.0 & 24.7 & 27.3 \\
Black Lagoon & 17.1 & 11.8 & 13.3 & 13.0 \\
Gibraltar Bay & 13.5 & 14.1 & 13.9 & 14.8 \\
& & & & \\
Adjusted uptake & & & & \\
Monguagon Creek & 14.1 & 14.1 & 11.7 & 12.5 \\
Black Lagoon & 18.4 & 18.4 & 22.0 & 19.9 \\
Gibraltar Bay & 17.8 & 16.7 & 18.5 & 18.7 \\
\hline
\end{tabular}

Sediment concentrations were chosen to include those likely in a moderate resuspension event ( 12 to $150 \mathrm{mg} \mathrm{l}^{-1}$ wet wt), and concentrations probable under extreme mixing conditions (600 to $1200 \mathrm{mg} \mathrm{l}^{-1}$ ). The lowest concentrations, 12 to $75 \mathrm{mg}^{-1}$, had little effect on or enhanced uptake, while medium concentrations ( 120 to $150 \mathrm{mg} \mathrm{l}^{-1}$ ) began to show inhibition of uptake. Thus a relatively severe resuspension event could cause a decrease in productivity of phytoplankton or metabolism of bacteria, while a less severe event might have little effect as shading and toxicity would be offset by nutrient or substrate availability.

Accuracy of bioassays in terms of the real world was difficult to determine. No doubt, the bioassays simplified the situation, as one small, well-mixed water mass under constant conditions was used for all treatments, whereas field conditions would be heterogeneous, complex, and changing. However, baseline data on biological effects under controlled conditions are needed before hypotheses can be formulated for design of field research. Absolute uptake values probably reflected higher phytoplankton productivity than most field conditions, because of the bright light in the incubator. In contrast, bacterial metabolism was probably underestimated because only one substrate was used in the bioassays.

Bioassay results were reasonably precise. The standard error of uptake for phytoplankton bioassays for a given date and treatment was generally an order of magnitude less than the mean uptake. The results were not quite as good for bacteria as for algae, but the standard error was seldom more than half of the mean. The precision of the results was reflected in the similarity among replicates and contributed to significant differences between treatments as shown by ANOVAs.

\section{Discussion}

\subsection{Bacterial bioassays}

Bacteria were chosen as one of the two functional groups of organisms for this investigation because 
they constitute a major link in the food web that comes in contact with toxic materials in the sediments. Further, some bacteria are known to thrive on certain toxic materials, while others respond negatively to the presence of the same materials (Colwell \& Grimes, 1986).

A large variety of metabolic effects could lead to the suppression of uptake of substrates by bacteria in the presence of both synthetic organic compounds and metals. Some of these effects include: alteration to the chemistry of cell membranes, suppression of the uptake of certain amino acids, interference in the synthesis of nucleic acids, and the disruption in certain catabolic pathways (Lal \& Saxena, 1982). Because these effects change due to both the concentration of the toxic substance and the type of bacteria present, a priori it is difficult to predict the response of the community to the presence of the materials. Combinations of certain substances appear to have a synergistic effect that is as yet not fully understood (Wong et al., 1978). For these reasons, bioassays become site- and time-dependent and must be repeated frequently.

The use of adenine as a substrate is somewhat surrounded in controversy with some authors (Karl \& Winn, 1984, 1986; Karl, 1981) attributing uptake to both algae and bacteria. Other authors (Fuhrman et al., 1986a, 1986b; Peele et al., 1985) have found either equivocal results in the offshore marine environment or unequivocal results nearshore that only bacteria take up adenine. Following the findings of Fuhrman et al. (1986a), this study assumed that, in enriched nearshore environments, adenine uptake was mediated almost exclusively by bacteria. In contrast, glucose uptake may be substantially affected by algal heterotrophy (Moll, 1984). Thus the rationale for shifting to adenine from glucose after the first set of experiments in late May and early June, 1986.

Bioassays with sediments are more complicated than with little or no suspended materials. The sediment can mask the effect of the toxic material due to its binding nature and shifts in redox potential. For these reasons, paired analyses comparing non-toxic sediments and contaminated sediments appear the most reliable bio- assays. But, this additional constraint adds considerable complexity to the experimental design in that the number of controls is greatly increased. The results from this study encourage use of such controls.

The results of the bioassays must be interpreted with caution because in some cases the sediment actually stimulated rather than suppressed uptake. This was often true at the lower sediment concentrations, and almost always when uptake was not corrected for biomass. Munawar et al. (1988) occasionally noticed a similar effect in phytoplankton bioassays during investigation of the effects of Toronto Harbour sediment on algae.

Isotope dilution in all experiments was possible by the introduction of non-radioactive substrate (adenine) with the sediment additions. This dilution could have the effect of reducing isotope uptake at high sediment concentrations thus confounding the experimental results. While the effect of isotope dilution was not investigated per se, three lines of reasoning suggest this was not a major problem. First, in many experiments substrate uptake did not decrease with increasing sediment concentrations. Only after the uptakes were adjusted for biomass did the suppressed uptakes change. If isotope dilution was important, unadjusted uptake rates would decline significantly given the two orders of magnitude increase in sediment concentration with the various additions for each set of bioassays. Second, most of the pore water incubations showed no decline in either adjusted or unadjusted uptake rates with increasing amounts of pore water additions. Clearly, isotope dilution was not operating in these experiments. Third, the effect of contaminated sediment was determined against the clean sediment control. Isotope dilution could mask the results only by substantial differences in dilution between the two sediment types. While this condition may have been true in a few cases, it is most unlikely to occur on a consistent basis.

The salient conclusion from this study was that when uptake of substrate was adjusted for bacterial biomass, a significant effect was observed due to the amount and type of sediment. In 1986 the reduction in uptake between the control 
( $0 \mathrm{mg} \mathrm{l}^{-1}$ sediment addition) and the highest concentration (1200 $\mathrm{mg} \mathrm{l}^{-1}$ sediment addition) was 65.3, 79.2, and 75.4 percent for Monguagon Creek, Black Lagoon, and Gibraltar Bay, respectively. This compares to a reduction of 39.6 percent for the clean Lake Michigan sediment addition. The pattern was similar for 1987 with the reductions of $61.7,76.9$, and 66.7 percent for Monguagon Creek, Black Lagoon, and Gibraltar Bay, respectively, and a reduction of 51.6 percent for the Lake Michigan sediment. These results imply a high level of sensitivity by the bacteria to the addition of the contaminated sediment.

A similar level of sensitivity was not observed by Ribo et al. (1985) using the Microtox bioassay with Detroit River samples. They found that of a total of 76 stations investigated, only four showed acute levels of toxicity. Two of these four sites were from the Trenton Channel, with one at the mouth of Monguagon Creek. These bioassays used Photobacterium phosphoreum and Detroit River water, but no sediment. Most of the Ribo et al. (1985) Microtox assays showed responses less than 20 percent different from the controls.

There have been a number of studies investigating the effect of specific toxic materials on microorganisms. Many of these studies have been summarized by Lal \& Saxena (1982). The results are highly variable with some compounds such as heptachlor proving extremely toxic to bacteria, while DDT and its derivatives were relatively innocuous to bacteria. Lal \& Saxena (1982) suggested that the variable nature of the results was attributed in part to the degree of susceptibility of the various bacteria species to the different toxic materials. Cunningham et al. (1986) came to the same conclusion using the Microtox bioassay from a set of experiments with samples from New Jersey and Pennsylvania.

Given the ephemeral nature of the results from previous investigations, the consistent results from this study are unusual. This consistency is especially interesting given the change in substrates over the two years, the various locations investigated, and the large range in seasons. Apparently, the experimental protocol used in this study was sufficiently different from the previous studies to generate a novel type of result. Perhaps the exposure of mid-river water samples, containing relatively unaffected microbes, to the toxic materials found in the sediments of the backwaters of the Trenton Channel elicited the significant response in the bioassays. In addition, Lal \& Saxena (1982) indicate that in many highly contaminated environments a natural bacterial population develops which actually metabolizes some of the toxicants; in some instances these bacteria become dependent on the toxicant as an energy source. Thus the bioassay response could be considerably different if conducted with populations from the backwater versus mid-river. Finally, a large number of the toxic substances in the backwaters of the Trenton Channel are metals (Fallon \& Horvath, 1985; Theis et al., 1988). These compounds have proven more toxic to most microorganisms than synthetic organic compounds (Wong et al., 1978). Further studies are needed on the types of responses observed in bioassays using a mixture of toxic materials versus a single class of compounds.

\subsection{Phytoplankton bioassays}

As autotrophs, phytoplankton are an important base to the food web, thus adverse effects on their growth or health may have repercussions on productivity of higher trophic levels. Phytoplankton are believed relatively sensitive organisms as subjects for bioassay investigations (Munawar \& Thomas, 1986).

Effects of contaminants can be grouped into three categories: changes in species composition and size structure, metabolic and physiological response, and ultrastructural response (Munawar et al., 1988). Because the first effect is long-term, only the second and third effects may be operating in these Trenton Channel bioassays. Broadly, decreased uptake with increasing sediment is caused by several factors: shading, toxicity, physical damage to cells, adsorption of nutrients to the sediment (decreasing their bioavailability), and other mechanisms. Lake Michigan sediment was believed to inhibit uptake primarily by shad- 
ing and possible cell damage, while an additional toxic response was observed from Trenton Channel sediment exposure. Toxicity includes a number of physiological responses which are different among species and contaminants and are not well understood, but include inhibition of photosynthesis from interference with electron transport, cell membranes, development and structure of chloroplasts, and the light and dark reactions (Lal \& Saxena, 1982; Munawar et al., 1988). The multiple metals and organic contaminants in Trenton Channel sediment may have unknown synergistic or antagonistic effects, of which only the net sum is observed. Combinations of metals have been shown to be more toxic to certain algae than were the same metals presented singly (Wong et al., 1978).

By expressing results of the Trenton Channel bioassays as percent reduction of uptake from controls to high sediment concentration, they can be compared with results from other sites and experimental protocols. Uptake adjusted for biomass decreased an average of over 90 percent between 0 and $1200 \mathrm{mg} \mathrm{l}^{-1}$ sediment in 1986 (Table 8). In 1987, from 75 to $600 \mathrm{mg} \mathrm{l}^{-1}$ the decrease in uptake averaged about 65 percent (Table 9). To observe only the toxic effect, not the particle effect, one may compare uptake rates in clean versus contaminated sediment for only one concentration. Monguagon Creek sediment reduced uptake 40 percent at $600 \mathrm{mg} \mathrm{l}^{-1}$ and 23 percent at $1200 \mathrm{mg} \mathrm{l}^{-1}$ compared to equal concentrations of Lake Michigan sediment. Similarly, Black Lagoon sediment reduced uptake 64 percent at $600 \mathrm{mg} \mathrm{l}^{-1}$ and 78 percent at $1200 \mathrm{mg} \mathrm{l}^{-1}$ compared to 600 and $1200 \mathrm{mg} \mathrm{l}^{-1}$ of Lake Michigan sediment.

The previous research with phytoplankton sediment bioassays most comparable to this study was that of Munawar \& Thomas (1986) and Munawar et al. $(1983,1985)$, who conducted elutriate bioassays using ${ }^{14} \mathrm{C}$ uptake, natural phytoplankton assemblages, and sediment from polluted sites around the Great Lakes. The following percentages of uptake reduction from Munawar's several studies were all from solutions of 20 percent elutriate. Because of water addition to the sediment, 20 percent elutriate corresponds to approximately 3 percent liquid actually derived from the sediment, while the phytoplankton bioassays from this study using $1200 \mathrm{mg} \mathrm{l}^{-1}$ sediment contained about 0.08 percent water. Sites closest to the three Trenton Channel sites of this study - just upstream of Fighting Island, and the mouth of the Detroit River - showed no trend in reduction of uptake with addition of elutriate (Munawar et al., 1985). Elutriate from just downstream of Belle Isle reduced uptake 17 to 20 percent, and that from northwest Lake Erie reduced uptake 15 to 25 percent, but the difference was nonsignificant for Lake Erie. Toronto Harbour sediment elutriate reduced uptake 20 to 30 percent, Toledo Harbor elutriate about 27 percent (Munawar \& Thomas, 1986), Niagara River elutriate 45 to 85 percent and Lake Ontario elutriate 28 to 48 percent (Munawar et al., 1983); ranges refer to different size fractions of phytoplankton. Overall, these uptake reductions were small compared to this study, considering the actual concentrations of sediment-derived material. The Detroit River sites studied by Munawar et al. (1985) may not have been as highly contaminated as those of this study.

Other studies investigated dealt with specific toxicants rather than field-collected sediment alone. Powers et al. (1982) adsorbed Aroclor, a $\mathrm{PCB}$, into the sediment. They then subjected a natural phytoplankton assemblage to the particles, from which Aroclor desorbed at a final concentration of $50 \mu \mathrm{g} \mathrm{l}^{-1}$. Compared to the control with clay only, Aroclor with sediment decreased uptake about 80 percent after one day (Powers et al., 1982). Suppression of uptake continued throughout the 3-day incubation. The high reduction in uptake, presence of sediment particles, and inclusion of the adsorption/desorption process are similar to the present study.

Wong et al. (1978) exposed Scenedesmus quadricauda cultures to a combination of ten metals at recommended water quality objective concentrations, which were generally determined from bioassays using a single metal. In culture media, productivity was inhibited 68 percent, and one-tenth the metals concentrations reduced 
uptake 40 percent, demonstrating the synergistic toxic effects of metals on phytoplankton. Water quality objective concentrations of metals added to algal cultures in Hamilton Harbour water, which itself contains metals, reduced uptake 78 percent, and one-tenth the concentrations reduced uptake 21 percent (Wong et al., 1978). These reductions in uptake are relatively large, and suggest that uptake reductions in the present study may be related to high concentrations of metals in Trenton Channel sediment.

\subsection{Relevance of bioassays}

All sediment and pore water bioassays were conducted in the laboratory. But every effort was made to maintain conditions as close to the natural environment as possible. Bioassays were usually conducted within 48 hours of collection, and never more than a few days after sample collection. Both sediment and incubation water were handled as little as possible before the bioassays and stored in dark cold rooms until analysis. All sediment containers were kept completely full, cold, and tightly stoppered until opened for bioassays. The operational principle was that an important component of the sediment was the volatile organic fraction which could be readily lost by casual treatment of the sediment. Finally, bacteria and phytoplankton populations used in the experiments were from the Trenton Channel and not preadapted to the environmental condition of the bioassays. This approach was used in order to simulate the probable circumstances surrounding an event which would cause resuspension of contaminated sediment in the Detroit River.

The 'freshness' of the natural populations of microorganisms was critical to the outcome of the experiments. An unplanned set of experiments demonstrated this fact. River water that was allowed to sit one extra day in the cold room was used as a second control for several phytoplankton bioassays. After four sets of bioassays, the results clearly showed that this was not a control because that extra day had the effect of signifi- cantly changing the uptake of substrate in comparison to the bioassays conducted the day before. When the experimental protocol was altered to run the controls on the same day, this 'control' effect disappeared.

The standard elutriate bioassay used by other investigators, where sediment is mixed with extra water, allowed to settle, and the water used after filtering, was modified for this study to make the protocol more ecologically relevant. Chapman et al. (1986) found that aged sediment-water mixtures and elutriates were not as toxic to Daphnia as freshly mixed sediment and water. Potential mechanisms for this were loss of volatile toxic material, sequential solution and binding or precipitation of the toxic component, or the rapid solution of a toxic component followed by slower solution of an antagonist (Chapman et al., 1986). When a resuspension event occurs in the field, the organisms present are instantly exposed to the whole sediment, and the bioassay methods chosen here reflect that process.

Pore water bioassays showed that toxicity was associated more with particles than the pore water. Some portions of the toxic contaminants were apparently bound or adsorbed to particles and did not enter the pore water during its preparation. The highest concentration of pore water $\left(10 \mathrm{ml} \mathrm{l}^{-1}\right)$ was derived from a quantity of sediment much higher than the highest concentration in whole-sediment bioassays (about $40 \mathrm{~g}$ versus $1.2 \mathrm{~g}$ ). Thus pore water was clearly much less toxic than an equivalent amount of whole sediment. However, these results do not suggest that pore water was not toxic. To the contrary, when pore water concentrations were raised to high enough levels, a significant response was induced (Giesy et al., 1988).

The conclusions from this study suggest that the sediments in the backwaters of the Trenton Channel are highly contaminated and pose a risk to the food web. Although those sediments do reside in backwaters, the contaminated material is found on the surface of the sediments implying that relatively minor mixing events can mobilize the toxic materials. Further, location of the contaminated material on the top of the sediment 
suggests a continuing input to these regions. Additional research should be conducted to track the movement of these toxicants through the food web.

\section{Acknowledgements}

This research was supported by the Large Lakes Research Station of the U.S. Environmental Protection Agency under Grant No. EPA-CR812569. The authors gratefully acknowledge the many useful suggestions made by Drs. K. Burnison and $\mathrm{P}$. Wong during the review process.

\section{References}

Brown, M. B. \& A. B. Forsythe, 1974. Robust tests for the equality of variances. J. Am. Stat. Ass. 69: 364-367.

Chapman, G., M. Cairns, D. Krawczyk, K. Mulueg, A. Nebeker \& G. Schuytema, 1986. Report on the toxicity and chemistry of sediments from Toronto and Toledo harbors. In; Rep. Dredging Subcommittee Great Lakes Wat. Qual. Bd. Internat. Joint Commiss., Windsor, Ontario, Canada: 91-118.

Colwell, R. R. \& D. J. Grimes, 1986. Evidence for genetic modification of microorganisms occurring in natural aquatic environments. In T. M. Poston \& R. Purdy (eds), Aquatic Toxicology and Environmental Fate: Ninth Volume. ASTM Spec. Tech. Pub. 921: 222-232.

Cunningham, V. L., M. S. Morgan \& R. E. Hannah, 1986. Effect of natural water source on the toxicity of chemicals to aquatic microorganisms. In T. M. Poston \& R. Purdy (eds), Aquatic Toxicology and Environmental Fate: Ninth Volume. ASTM Spec. Tech. Pub. 921: 436-449.

Davis, C. O. \& M. S. Simmons, 1979. Water chemistry and phytoplankton field and laboratory procedures. Great Lakes Res. Div. Spec. Rep. No. 70. Univ. Mich., Ann Arbor, Mi. $88 \mathrm{pp}$.

Dixon, W. J., M. B. Brown, L. Engelman, J. W. Frane, M. A. Hill, R. I. Jennrich \& J. D. Toporek, 1981. BMDP Statistical Software. Univ. California Press, Los Angeles. 726 pp.

Fallon, M. E. \& F. J. Horvath, 1985. Preliminary assessment of contaminants in soft sediments of the Detroit River. J. Great Lakes Res. 11: 373-378.

Fitzwater, S. E., G. A. Knauer \& J. H. Martin, 1982. Metal contamination and its effect on primary production measurements. Limnol. Oceanogr. 27: 544-551.

Fox, D. J. \& K. E. Guire, 1976. Documentation for MIDAS. Statist. Res. Lab., Univ. Michigan, Ann Arbor, Mi. 203 pp.
Fuhrman, J. A., H. W. Ducklow, D. L. Kirchman, J. Hudak, G. B. McManus \& J. Kramer, 1986a. Does adenine incorporation into nucleic acids measure total microbial production? Limnol. Oceanogr. 31: 627-636.

Fuhrman, J. A., H. W. Ducklow, D. L. Kirchman, J. Hudak \& G. B. McManus, 1986b. Adenine and total microbial production: a reply. Limnol. Oceanogr. 31: 1395-1400.

Furlong, E. T., D. S. Carter \& R. A. Hites, 1988. Organic contaminants in sediments from the Trenton Channel of the Detroit River, Michigan. J. Great Lakes Res. 14: 489-501.

Giesy, J. P., R. L. Graney, J. L. Newsted, C. J. Rosiu, A. Benda, R. G. Kreis \& F. J. Horvath, 1988. A comparison of three sediment bioassay methods for Detroit River sediments. Env. Toxicol. Chem. 7: 483-498.

Hobbie, J. E., R. J. Daley \& S. Jasper, 1977. Use of Nuclepore filters for counting bacteria by fluorescence microscopy. Appl. Env. Microbiol. 33: 1225-1228.

Karl, D. M., 1981. Simultaneous rates of ribonucleic acid and deoxyribonucleic acid synthesis for estimating growth and cell division of aquatic microbial communities. Appl. Env. Microbiol. 42: 802-810.

Karl, D. M. \& C. D. Winn, 1984. Adenine metabolism and nucleic acid synthesis: applications to microbiological oceanography, In; J. E. Hobbie \& P. J. Williams (eds), Heterotrophic Activity in the Sea: 197-215. Plenum, New York.

Karl, D. M. \& C. D. Winn, 1986. Does adenine incorporation into nucleic acids measure total microbial production?: a response to comments by Fuhrman et al. Limnol. Oceanogr. 31: 1384-1394.

Lal, R. \& D. M. Saxena, 1982. Accumulation, metabolism and effects of organochlorine insecticides on microorganisms. Microbiol. Rev. 46: 95-127.

Moll, R. A., 1984. Heterotrophy by phytoplankton and bacteria in Lake Michigan. Verh. Int. Ver. Limnol. 22: 431-434.

Moll, R. A. \& M. Brahce, 1986. Seasonal and spatial distribution of bacteria, chlorophyll, and nutrients in nearshore Lake Michigan. J. Great Lakes Res. 12: 52-62.

Mount, D. I. \& T. J. Norberg, 1984. A seven-day life-cycle cladoceran toxicity test. Soc. Env. Tox. Chem. 3: 425-434.

Munawar, M. \& R. L. Thomas, 1986. Bioassessment of Toronto-Toledo sediments. In; Rep. Dredging Subcommittee Great Lakes Wat. Qual. Bd. Internat. Joint Commiss., Windsor, Ontario, Canada: 9-50.

Munawar, M., A. Mudroch, I. F. Munawar \& R. L. Thomas, 1983. The impact of sediment-associated contaminants from the Niagara River mouth on various size assemblages of phytoplankton. J. Great Lakes Res. 9: 303-313.

Munawar, M., R. L. Thomas, W. Norwood \& A. Mudroch, 1985. Toxicity of Detroit River sediment-bound contaminants to ultraplankton. J. Great Lakes Res. 11: 264-274.

Munawar, M., P. T. S. Wong \& G-Y. Rhee, 1988. The effects of contaminants on algae: an overview. In; N.W. 
Schmidtke (ed), Toxic Contamination in Large Lakes, Vol. I: Chronic Effects of Toxic Contaminants in Large Lakes. pp. 113-160. Lewis Publishers, Inc., Chelsea, Michigan.

Peele, E. R., R. E. Murray, R. B. Hanson, L. R. Pomeroy \& R. E. Hodson, 1985. Distribution of microbial biomass and secondary production in a warm-core Gulf Stream ring. Deep-Sea Res. 32: 1393-1403.

Powers, C. D., G. M. Nau-Ritter, R. G. Rowland \& C. F. Wurster, 1982. Field and laboratory studies of the toxicity to phytoplankton of polychlorinated biphenyls (PCBs) desorbed from fine clays and natural suspended particulates. J. Great Lakes Res. 8: 350-357.

Pugsley, C. W., P. D. N. Hebert, G. W. Wood, G. Brotea \& T. W. Obal, 1985. Distribution of contaminants in clams and sediments from the Huron-Erie corridor. I. PCBs and octachlorostyrene. J. Great Lakes Res. 11: 275-289.

Ribo, J. M., B. M. Zaruk, H. Hunter \& K. E. Kaiser, 1985. Microtox toxicity test results for water samples from the Detroit River. J. Great Lakes Res. 11: 297-304.

Smith, V. E., J. M. Spurr, J. C. Filkins \& J. J. Jones, 1985. Organochlorine contaminants of wintering ducks foraging on Detroit River sediments. J. Great Lakes Res. 11: 231-246.

Strickland, J. D. H. \& T. R. Parsons, 1972. A practical handbook of seawater analysis. Fish. Res. Bd. Can. Bull. No. 167.310 pp.

Struger, J., D. V. Weseloch, D. J. Hallett \& P. Mineau, 1985. Organochlorine contaminants in herring gull eggs from the Detroit River and Saginaw Bay (1978-1982): contaminant discriminants. J. Great Lakes Res. 11: 223-230.

Theis, T. L., T. C. Young \& J. V DePinto, 1988. Factors affecting metal partitioning during resuspension of sediments from the Detroit River. J. Great Lakes Res. 14: 216-226.

U.S. Environmental Protection Agency/U.S. Army Corps of Engineers, 1977. Ecological evaluation of proposed discharge of dredged material into ocean waters. Env. Effects Lab. U.S. Army Corps Engin. Waterways Effects Lab., Vicksburg, Miss.

Wong, P. T. S., Y. K. Chau \& P. L. Luxon, 1978. Toxicity of a mixture of metals on freshwater algae. J. Fish. Res. Bd. Can. 35: 479-481. 